\title{
Design and evaluation of chalconeimine derivatives as $\alpha$-amylase inhibitors
}

\author{
Prithivirajan Balu1, Jebastin Sonia Jas ${ }^{1,2} \&$ Marimuthu Govindaraj ${ }^{3, *}$
}

${ }^{1}$ Research and Development Centre, Bharathiar University, Coimbatore-641046, India; ${ }^{2}$ Department of Chemistry, IFET College of Engineering, Villupuram-605108, India; 3Department of Chemistry, Swami Dayananda College of Arts and Science, Manjakkudi-612610, Tiruvarur District, India; *Corresponding author: E-mail: gmarimuuthu@gmail.com

Received July 16, 2019; Accepted July 28, 2019; Published July 31, 2019

DOI: $10.6026 / 97320630015523$

\begin{abstract}
:
Alpha-amylase is a known target for type II diabetes. Therefore, it is of interest to design $\alpha$-amylase inhibitors based on hydrazone scaffold. The structure of these hybrids was confirmed by spectroscopic analysis (IR, ${ }^{1} \mathrm{H}$-and ${ }^{13} \mathrm{C}$ NMR). All the compounds have potential inhibitory properties as shown by in vitro $\alpha$-amylase inhibition activity. The compound 5-((1Z,3Z)-3-(benzo[d][1,3]dioxol-5-yl)-3-((2-chloropyridin-3yl)imino)prop-1-en-1-yl)-2-(difluoromethoxy)phenol(4a) in $100 \mu \mathrm{g} / \mathrm{mL}$ concentration showed a high inhibition of $85.23 \%$. In vitro $\alpha$-amylase inhibition was further supported by docking studies of compound against the active site of pig pancreatic $\alpha$-amylase (PDB ID: 3L2M). Docking studies revealed that the bonding interactions found between the compound and human pancreatic $\alpha$-amylase are similar to those responsible for $\alpha$-amylase inhibition by acarbose.
\end{abstract}

Keywords: Molecular docking, diabetes, alpha-amylase, hydrogen bond, hydrazone, chalcone.

\section{Background:}

Diabetes is a multi-factorial disorder of the pancreas, in which the pancreas fails to perform its function to produce insulin hormone properly in the body. It involves multiple disorders like hyperglycemia, glycosuria and abnormal metabolism of lipids, carbohydrates and proteins [1, 2]. This affects the human body at physiological, physical and social level. It has been known as the 3rd leading cause of death in humans along with other diseases such as cancer, cerebro-vascular and heart Hypoglycemic medication is helps to lower the blood sugar level in body or treat the other severe symptoms and complications of diabetes mellitus [2]. The side effects of these medications include extreme hypoglycemia, liver cell injury, lactic acidosis, digestive discomfort, permanent neurological deficit, headache, dizziness and even death $[3,4]$. The basic challenge in curing diabetes is to maintain blood glucose level close to normal levels [5-10]. These therapies are used as mono therapy or in combination for optimal control of glycemia [11-14]. As mentioned before that these drugs are normally expensive and come with side effects. These drugs have their limitations due to low pharmacokinetic properties, secondary failure rates and relative bad effects [15-21]. Thus, there is a need for efficient class of compounds to reduce the side effects. Molecular docking is a competent tool for novel micro molecule drugs discovery for targeting protein. This study has been carried out in order to identify effective, selective and efficient antidiabetic Lead compound and its analogues.

Chalcone is a class of open-chain flavonoids that is not only biosynthesized by plants but also can be prepared synthetically. The simplest chalcone can be prepared by an aldol condensation between a benzaldehyde and an acetophenone in the presence of base [22-24]. Hydrazones of chalcones have shown a wide variety of pharmacological effects, including anti-inflammatory and anticancer activities [25-29]. Despite the comprehensive biological studies on chalcones, reports on their anti-diabetic activity are limited [30]. Significant advances have been made in the past few years in the isolation and preparation of several hydrazones of chalcones derivatives.

\section{Material and methods:}

Chemistry:

Thin layer chromatography (TLC) was used to examine the progress of the reaction. Open glass vessels were used to make a decision for the dissolving on outstanding softening mechanical assembly and were uncorrected. $\mathrm{H} 1$ and $13 \mathrm{C}$ atomic enticing reverberation ( $\mathrm{H} 1$ proton magnetic resonance and 13CNMR) 

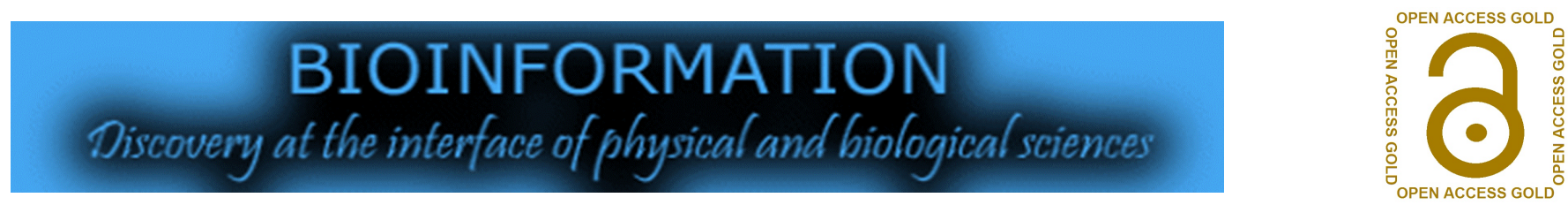

spectra were recorded on Bruker Avance II four hundred proton magnetic resonance spectroscope $(400 \mathrm{MHz})$ at $298 \mathrm{~K}$, in correct deuterated dissoluble. Concoction move were accounted for as $\delta$ (ppm) with relation to tetra methyl silane (TMS) within allowable limit. Infrared spectra (IR) were recorded as $\mathrm{KBr}$ pellet on Shimadzu FT-IR spectroscope.

\section{Preparation of AC-CdO-TiO 2 nonocomposite material by precipitation method:}

AC-CdO- $\mathrm{TiO}_{2}$ nanocomposite material was synthesized by precipitation method. Initially cadmium acetate dihydrate $(0.4 \mathrm{M})$ were dissolved in anhydrous ethanol solution beaker A. $0.4 \mathrm{~m}$ citric acid and tetra isopropyl orthotitanate were in ethanol is taken as another solution beaker B and Activated carbon (AC) were dissolved in anhydrous ethanol solution beaker $\mathrm{C}$, the solution A and solution $\mathrm{C}$ is added to Solution beaker $\mathrm{B}$ and stirred well. Then to thise 2 drops $\mathrm{NH}_{4} \mathrm{OH}$ is added at room temperature under vigorous stirring until the precipitate was formed. The obtained precipitate was washed with water and ethanol. Then the precipitate was collected and dried in oven at $100^{\circ} \mathrm{C}$ for $12 \mathrm{hrs}$. The resulting powder was finally calcinated at $500^{\circ} \mathrm{C}$ at $4 \mathrm{hrs}$.

General procedure for the Synthesis of (E)-1-(4-

(difluoromethoxy)-3-hydroxyphenyl)-3-phenylprop-2-en-1-one(3): 4-(difluoromethoxy)-3-hydroxybenzaldehyde 1 (0.02 mol) and 1(benzo[d][1,3]dioxol-5-yl)ethanone $2(0.02 \mathrm{~mol})$ were dissolved in $30 \mathrm{ml}$ of alcohol. To this reaction mixture $40 \% \mathrm{NaOH}(10 \mathrm{ml})$ and AC-CdO- $\mathrm{TiO}_{2}$ nanoparticles catalyst $(0.003 \mathrm{~g})$, in ethanol $(5 \mathrm{~mL})$ were added. TLC followed the progress of the reaction. After completion of the reaction, the mixture was filtered to remove the catalyst and the filtrate was taken in ether, washed with water and dried over anhydrous sodium sulfate. Removal of solvent gave the crude product which was recrystallized from methanol to obtain the pure compounds.m.p:960 C; M.F: $\mathrm{C}_{17} \mathrm{H}_{12} \mathrm{~F}_{2} \mathrm{O}_{5} ; \mathrm{M} . W: 334$.

General procedure for the Synthesis of 5-((1Z, 3Z)-3(benzo[d][1,3]dioxol-5-yl)-4-(substituted pyridin-2-yl)buta-1,3dien-1-yl)-2-(difluoromethoxy)phenol (4a-e):

(E)-1-(4-(difluoromethoxy)-3-hydroxyphenyl)-3-phenylprop-2-en-1one $3(0.01 \mathrm{~mol})$ and substituted aniline $(0.01 \mathrm{~mol})$ was dissolved in ethanol $(20 \mathrm{ml})$. To this mixture $\mathrm{AC}-\mathrm{CdO}-\mathrm{TiO}_{2}$ nano particles was added and it was refluxed for $3 \mathrm{hrs}$. On cooling and dilution with ice-cold water, a solid mass separated out. It was re-crystallized from ethanol.

\section{Docking studies:}

X-ray crystal structures of pig pancreatic alpha-amylase (PDB Id: 3L2M) were retrieved from the Protein Data Bank [31]. To put together the receptor for docking studies, co-crystallized ligand and water molecules were eliminated. At the same time polar hydrogen atoms and Kollman-united costs have been protected by the DNA Gyrase receptor. The essential pdb and pdbqt documents of ligands and Pig pancreatic alpha-amylase receptor were prepared for the
AutoDock 4.2 software [32]. The usual docking protocol was applied in the AutoDock Vina in PyRx 0.8 software [33]. The docking results were analyzed using Discovery Studio 4.0 (Accelrys, Inc. San Diego, CA 92121, U.S.).

\begin{tabular}{llllll}
\multicolumn{6}{l}{ Table 1: Physical data of various synthesized compounds } \\
\hline Compound & Color & Mol. Formula & $\begin{array}{l}\text { Mol. } \\
\text { weight }\end{array}$ & Solubility & $\begin{array}{l}\text { Melting } \\
\text { point }\left({ }^{\circ} \mathrm{C}\right)\end{array}$ \\
\hline $4 \mathrm{a}$ & Yellow & $\mathrm{C}_{22} \mathrm{H}_{15} \mathrm{ClF}_{2} \mathrm{~N}_{2} \mathrm{O}_{4}$ & 444 & Ethanol & 157 \\
$4 \mathrm{~b}$ & Yellow & $\mathrm{C}_{22} \mathrm{H}_{15} \mathrm{ClF}_{2} \mathrm{~N}_{2} \mathrm{O}_{4}$ & 444 & Ethanol & 133 \\
$4 \mathrm{c}$ & Yellow & $\mathrm{C}_{22} \mathrm{H}_{15} \mathrm{ClF}_{2} \mathrm{~N}_{2} \mathrm{O}_{4}$ & 444 & Ethanol & 148 \\
$4 \mathrm{~d}$ & $\begin{array}{l}\text { Pale } \\
\text { Yellow }\end{array}$ & $\mathrm{C}_{23} \mathrm{H}_{18} \mathrm{~F}_{2} \mathrm{~N}_{2} \mathrm{O}_{4}$ & 424 & Ethanol & 128 \\
$4 \mathrm{e}$ & $\begin{array}{l}\mathrm{C}_{23} \mathrm{H}_{18} \mathrm{~F}_{2} \mathrm{~N}_{2} \mathrm{O}_{4} \\
\text { Pale }\end{array}$ & 424 & Ethanol & 118 \\
& Yellow & & & & \\
\hline
\end{tabular}

\begin{tabular}{llllll}
\multicolumn{6}{c}{ Table 2: Data from IR spectra of chalconeimine derivatives (4a-e) } \\
\hline \multirow{2}{*}{ Compounds } & \multicolumn{5}{l}{ FREQUENCY cm $^{-1}$} \\
& C=O & C=N & Ali C-H & CH=CH & ARO C-H \\
\hline 4a & 1666 & 1597 & 2966 & 1452 & 3089 \\
4b & 1645 & 1586 & 2924 & 1425 & 3084 \\
4c & 1645 & 1589 & 2924 & 1448 & 3084 \\
4d & 1625 & 1586 & 2926 & 1452 & 3093 \\
4e & - & 1667 & 2924 & 1450 & 3088 \\
\hline
\end{tabular}

Table 3: Data from ${ }^{1} \mathrm{H}$ NMR spectra of hyrazone derivatives (4a-e)

\begin{tabular}{llll}
\hline Compounds & $\mathbf{- C H}_{\mathbf{2}}$ & $\mathbf{C H F}_{2}$ & Aromatic protons \\
\hline $\mathbf{4 a}$ & $6.30(2 \mathrm{H}$,singlet $)$ & $7.48(1 \mathrm{H}$, singlet $)$ & $7.43-8.36(11 \mathrm{H}$, multiplet $)$ \\
$\mathbf{4 b}$ & $6.60(2 \mathrm{H}$, singlet $)$ & $7.47(1 \mathrm{H}$, singlet $)$ & $7.47-7.95(11 \mathrm{H}$, multiplet $)$ \\
$\mathbf{4 c}$ & $6.55(2 \mathrm{H}$, singlet $)$ & $7.49(1 \mathrm{H}$, singlet $)$ & $7.43-8.38(11 \mathrm{H}$, multiplet $)$ \\
$\mathbf{4 d}$ & $6.58(2 \mathrm{H}$, singlet $)$ & $7.46(1 \mathrm{H}$, singlet $)$ & $7.28-7.96(11 \mathrm{H}$, multiplet $)$ \\
$\mathbf{4 e}$ & $6.55(2 \mathrm{H}$, singlet $)$ & $7.41(1 \mathrm{H}$, singlet $)$ & $7.14-8.38(11 \mathrm{H}$, multiplet $)$ \\
\hline
\end{tabular}

Inhibition assay for $\alpha$-Amylase activit:

A stock solution of $10 \mathrm{mg} / 10 \mathrm{~mL}$ concentration was prepared using DMSO solvent. Activity of amylase was assayed with different concentrations $(50,100,200 \mu \mathrm{g} / \mathrm{mL})$ of sample with control and reagent solution without test sample was used as control. Starch solution $(1 \% w / v)$ or $(0.5 \% w / v)$ was prepared by stirring and boiling $0.5 \mathrm{~g}$ of soluble potato starch in $50 \mathrm{~mL}$ of deionized water for 15 minutes. The enzyme solution $(1 \mathrm{unit} / \mathrm{mL})$ was prepared by mixing $100 \mathrm{mg}$ in $100 \mathrm{~mL}$ of $20 \mathrm{mM}$ sodium phosphate buffer $(\mathrm{pH}$ 6.9). The color reagent was a solution containing $96 \mathrm{mM} \mathrm{3,5-}$ dinitrosalicylic acid (DNSA) (20 mL), 5.31 M sodium potassium tartrate in $2 \mathrm{M} \mathrm{NaOH}(8 \mathrm{~mL})$ and deionized water $(12 \mathrm{~mL})$. Acarbose was used as a standard at the concentration of $1 \mathrm{mg} / \mathrm{mL}$. $100 \mu \mathrm{l}$ of test solution and $100 \mu \mathrm{L}$ of enzyme solution were mixed in viols and incubated at $25^{\circ} \mathrm{C}$ for $30 \mathrm{~min}$. To this mixture $100 \mu \mathrm{L}$ of color reagent was added and the mixture was heated on water bath at $85^{\circ} \mathrm{C}$ for $15 \mathrm{~min}$. Further, the reaction mixture was removed from water bath, cooled and absorbance value determined at $595 \mathrm{~nm}$. Individual blanks were prepared for correcting the background absorbance. Control experiment was conducted in the same manner by replacing the drug sample with $1 \mathrm{~mL}$ DMSO. Inhibition percentage of $\alpha$ - amylase was calculated by the formula [34]. Enzyme activity was calculated and percentage of inhibition is $(($ Control - Test $) / 100) \times 100$. 

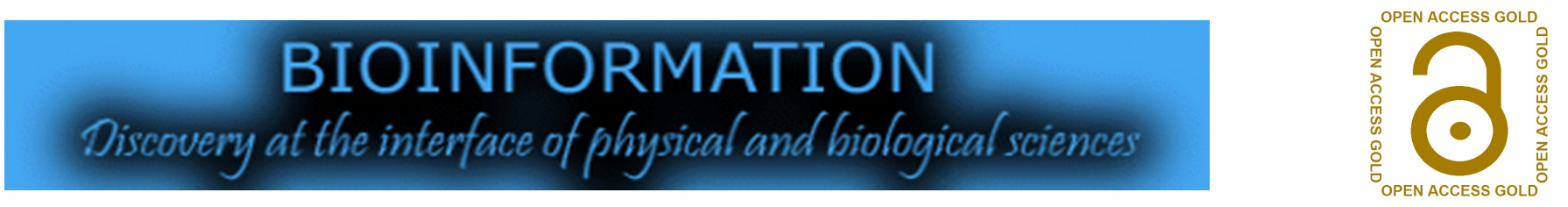

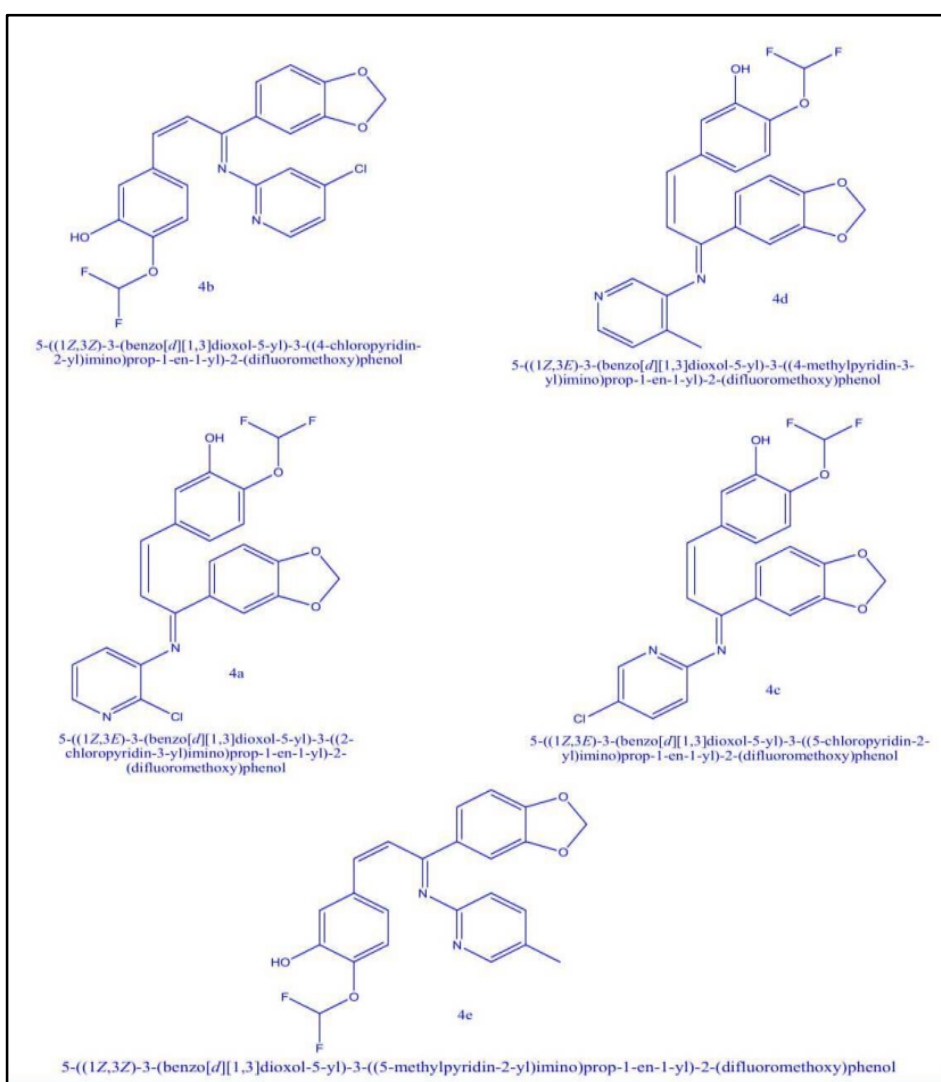

Figure 1: Schematic representation of structures of chalconeimine derivatives (4a-e)

\begin{tabular}{|c|c|c|}
\hline Compound & Concentration $(\mu \mathrm{g} / \mathrm{mL})$ & \% Inhibition \\
\hline & 50 & 70.84 \\
\hline \multirow[t]{3}{*}{$4 a$} & 100 & 85.23 \\
\hline & 200 & 86.84 \\
\hline & 50 & 77.18 \\
\hline \multirow[t]{3}{*}{$4 \mathrm{~b}$} & 100 & 81.35 \\
\hline & 200 & 83.64 \\
\hline & 50 & 54.82 \\
\hline \multirow[t]{3}{*}{$4 c$} & 100 & 68.58 \\
\hline & 200 & 73.34 \\
\hline & 50 & 76.58 \\
\hline \multirow[t]{3}{*}{$4 \mathrm{~d}$} & 100 & 75.03 \\
\hline & 200 & 77.84 \\
\hline & 50 & 50.12 \\
\hline \multirow[t]{3}{*}{$4 \mathrm{e}$} & 100 & 69.87 \\
\hline & 200 & 71.93 \\
\hline & 50 & 56.69 \\
\hline \multirow[t]{2}{*}{ Acarbose } & 100 & 63.85 \\
\hline & 200 & 69.78 \\
\hline
\end{tabular}

\section{Results and Discussion:}

Table 1 show all the physical data like color, molecular formula, molecular weight, solubility, melting point, of synthesized compounds. The IR frequencies of compounds 4a-e is shown in Table 2 in which the $C=\mathrm{N}$ stretching frequency appear at 1586-1667 $\mathrm{cm}^{-1}$. Aromatic $(\mathrm{CH})$ stretching frequencies appear at $3084-3093 \mathrm{~cm}^{-1}$ and stretching frequency observed at $1625-1666 \mathrm{~cm}^{-1} \mathrm{C}=\mathrm{O}$ group present in the derivatives. The ${ }^{1} \mathrm{H}$ NMR chemical shift values of compound (4a-e) given in Table 3 . The singlet observed in the range $6.30-6.60 \mathrm{ppm}$ is due $-\mathrm{CH}_{2}$ methylene proton of $3^{\prime}, 4^{\prime}-$ methylenedioxy acetophenone moiety proton. The singlet observed at $7.41-7.49 \mathrm{ppm}$ is due $-\mathrm{CH}$ proton of $-\mathrm{CHF}_{2}$ moeity. The signals appearing 7.14-8.38ppm are obviously due to aromatic protons. The five chalconeimine derivatives (4a-e) shown in Figure 1a were taken for docking studies. These compounds are synthesized and their structures have been determined by $\mathrm{IR}, 1 \mathrm{H}$ and ${ }^{13} \mathrm{CNMR}$ spectroscopy.

\section{In vitro a-amylase inhibition:}

All the synthesized compounds (4a-e) and standard drug were explored for their in vitro $\alpha$ - amylase inhibition studies at different concentrations $(50,100,200 \mu \mathrm{g} / \mathrm{mL})$ as shown in the Table 4 . All the compounds showed good $\%$ inhibition of $\alpha$-amylase when compared with standard drug acarbose. Compound $\mathbf{4 b}$ and $\mathbf{4 d}$ were found to be more potent among all the synthesized compounds when explored at the concentration of $50 \mu \mathrm{g} / \mathrm{mL}$. Compound $\mathbf{4 d}$ shows $76.58 \%$ inhibition followed by $\mathbf{4 b}$ with $77.18 \%$ inhibition. There was a significant rise in $\%$ inhibition when concentration has been changed to $100 \mu \mathrm{g} / \mathrm{ml}$ from $50 \mu \mathrm{g} / \mathrm{mL}$. Among all, 4b shows $81.35 \%$ inhibition followed by 4 a which showed $85.23 \%$ inhibition at $100 \mu \mathrm{g} / \mathrm{ml}$. Inspired by the results obtained at $100 \mu \mathrm{g} / \mathrm{mL}$ concentration, all the synthesized compounds were further screened for there in vitro $\alpha$-amylase inhibition at $200 \mu \mathrm{g} / \mathrm{mL}$. All compounds exhibited a linear rise in $\%$ inhibition.

\begin{tabular}{lccccccc}
\multicolumn{6}{l}{ Table 5: Binding energy of docked compounds (4a-e) } \\
\hline $\begin{array}{l}\text { Compound } \\
\text { Banding energy }\end{array}$ & & & & & & & \\
& -8.9 & -8.9 & -8.3 & -8.7 & -8.5 & -7.8 \\
\hline
\end{tabular}

\section{Docking studies:}

Interactions between inhibitors and active site of the target protein can be explored using molecular docking studies. The above results showed that all the synthesized molecules were stronger inhibitors of alpha-amylase as compared to acarbose. Therefore, for ascertaining the binding conformation and interactions responsible for the activity, docking simulation of compound $4 \mathbf{a}$ and $\mathbf{4 d}$ was performed against active site of pig pancreatic alpha-amylase (PDB ID: 3L2M). Ligands taken for the docking studies are shown in Figure 1a. Pig pancreatic alpha-amylase protein is considered as target protein for this study. Its structure was taken from RCSB Protein Data Bank (PDB) with PDB ID: 3L2M as shown in Figure 2. 


\section{BIOINFORMATION \\ Discovery at the interface of physical and biological sciences}

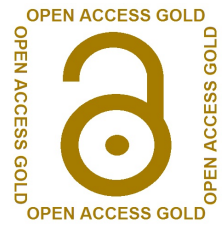

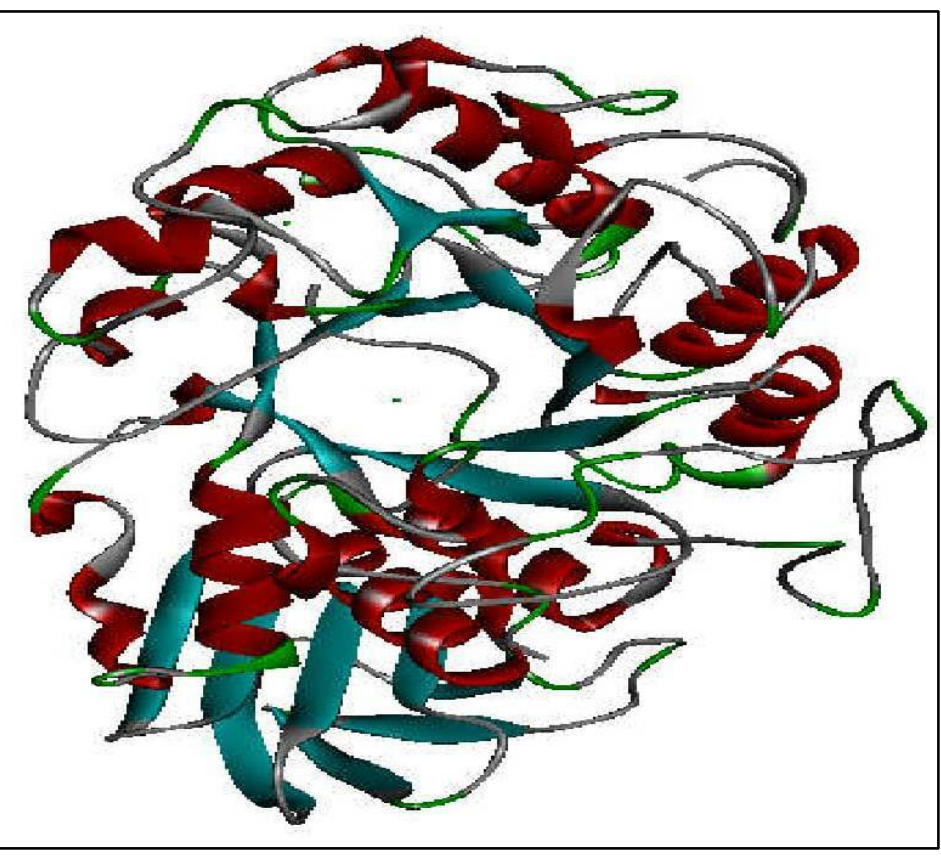

Figure 2: 3D Structure of X-ray crystallographic analysis of pig pancreatic alpha-amylase with alpha-cyclodextrin (PDB ID: 3L2M)

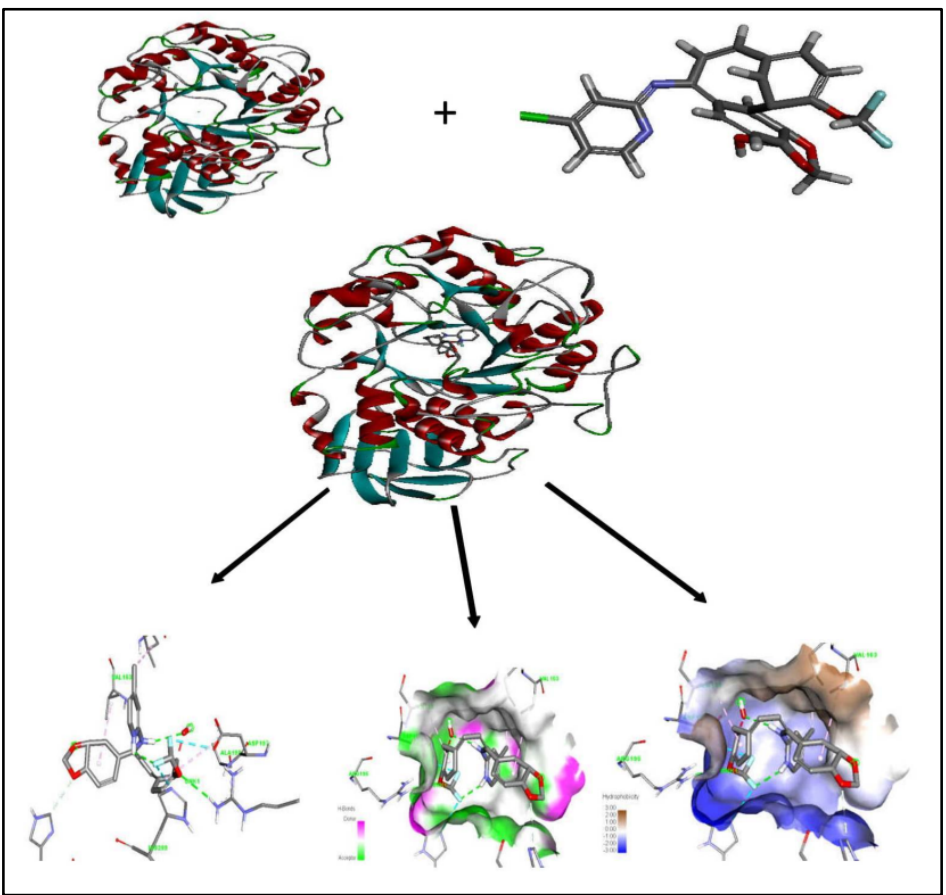

Figure 3: Binding of pig pancreatic alpha-amylase, with compound $4 a$

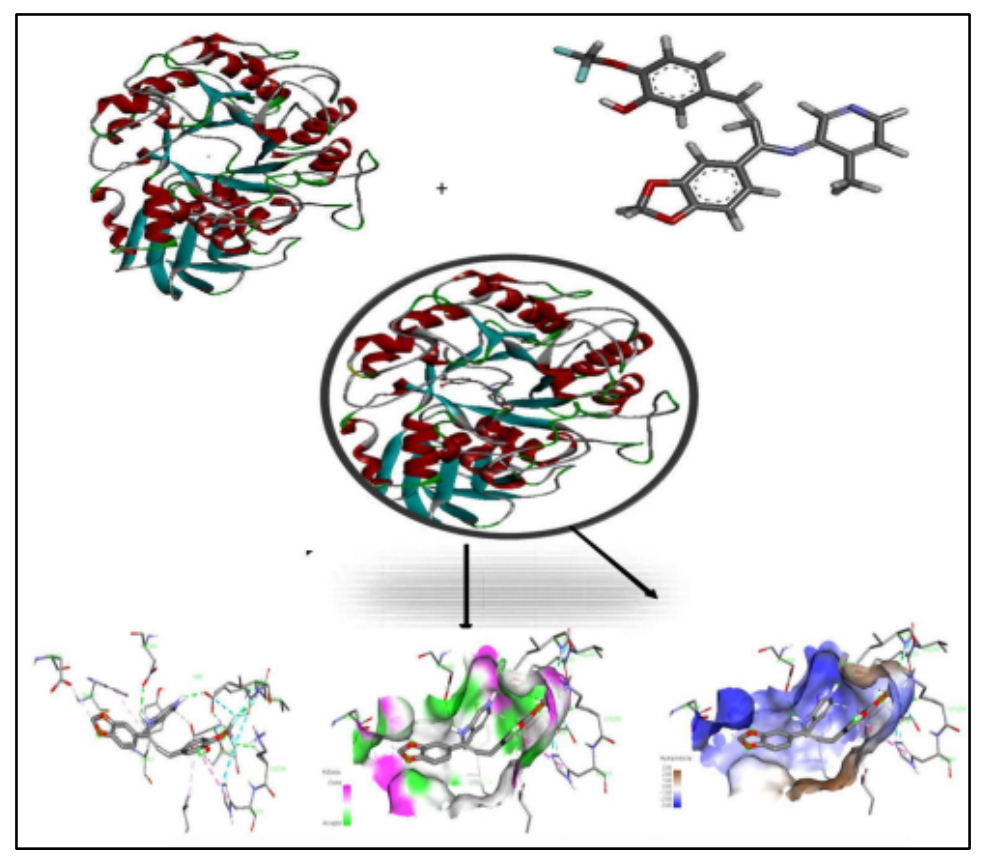

Figure 4: Binding of pig pancreatic alpha-amylase, with compound $4 b$

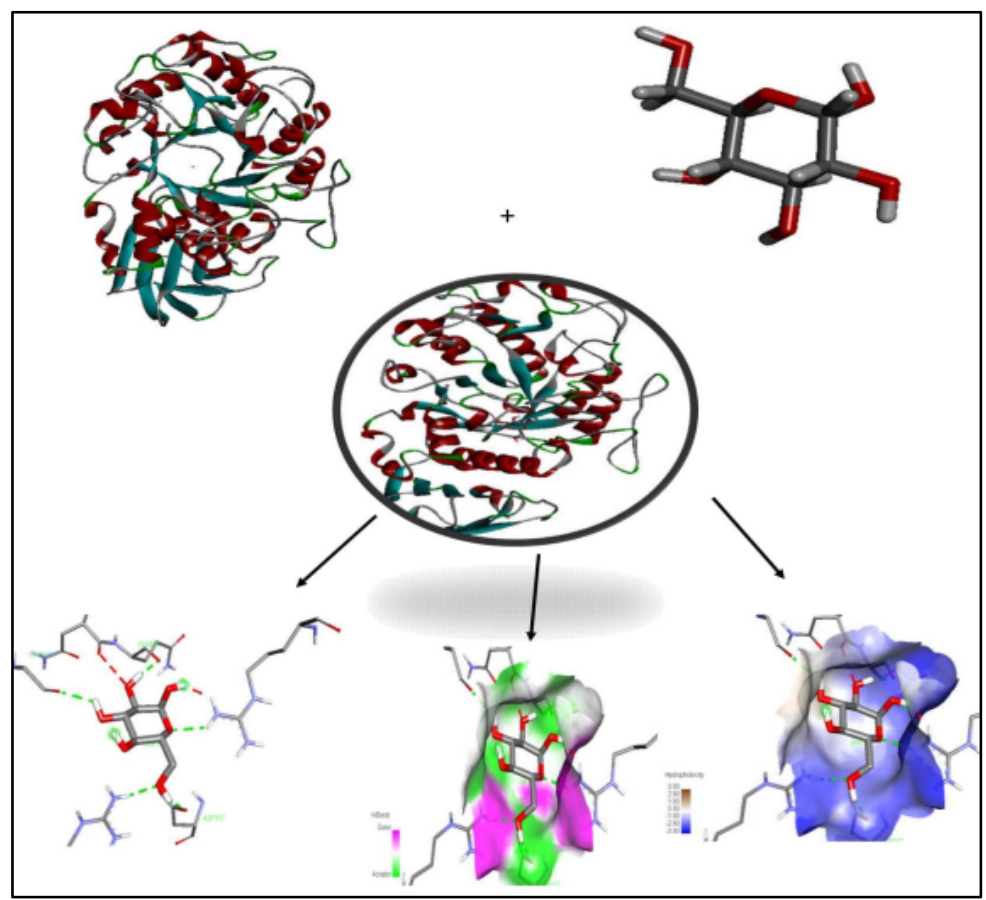

Figure 5: Binding of pig pancreatic alpha-amylase, with cocrystallized ligand 

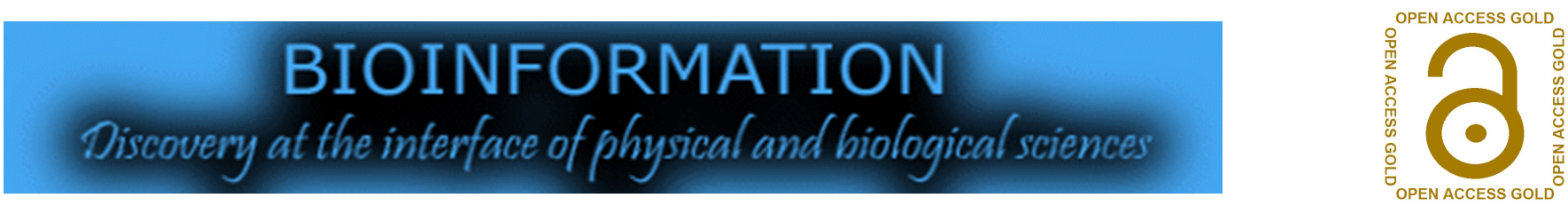

\begin{tabular}{|c|c|c|c|c|c|c|c|c|c|}
\hline Compound & Type of interaction & Between & Distance & Type of interaction & Between & Distance & Type of interaction & Between & Distance \\
\hline & & NH-0 (GLC 701) & 3.04 & & & & & & \\
\hline \multirow[t]{3}{*}{$4 \mathrm{a}$} & Hydrogen bon & $\mathrm{H}-0$ (GLU 233) & 2.53 & Halogen & F-0 (GLU 233) & 2.99 & pi-pi interaction & TYR 62 & 4.57 \\
\hline & & NH-O (ALA 198) & 2.72 & & & & Alkyl Interaction & VAL 163 & 5.23 \\
\hline & & o-NH (ARG 195) & 2.86 & & F-OD1(ASP 197) & 3.65 & Alkyl Interaction & LEU 165 & 4.09 \\
\hline \multirow[t]{4}{*}{$4 \mathrm{~b}$} & Hydrogen bon & NH-F (HIS 299) & 2.55 & Halogen & F-NE2(HIS299) & 3.31 & Alkyl Interaction & ALA 198 & 5.35 \\
\hline & Accptor-aceptor & $\mathrm{o}-\mathrm{o} 2$ (GLC 701) & 2.83 & & & & Alkyl Interaction & ILE 235 & 3.99 \\
\hline & & N-OD2 (ASP 300) & 5.53 & & & & Alkyl Interaction & LYS 200 & 3.82 \\
\hline & & N-OD1 (ASP 191) & 5.41 & & & & & & \\
\hline \multirow[t]{5}{*}{$4 c$} & Charge -change & N-OE1 (GLU233) & 5.06 & Halogen & F-OD2 (ASP 356) & 3.15 & Pi-Alkyl & HIS 201 & 4.82 \\
\hline & & NH-oD2 (ASP 300) & 2.44 & & F-CD(GLU 233) & 3.62 & Pi-Alkyl & TYR 62 & 4.29 \\
\hline & & NH-OE1 (GLU 233) & 2.28 & & F-O(GLU 233) & 3.44 & Pi-Alkyl & TRP 58 & 4.57 \\
\hline & & NH-F (LYS200) & 2.54 & & F-C (ILE 235) & 3.52 & Pi-Alkyl & ALA 198 & 5.2 \\
\hline & & & & & & & Pi-Alkyl & LEU 162 & 4.82 \\
\hline \multirow[t]{4}{*}{$4 \mathrm{~d}$} & Hydrogen bon & NH-F (ILE 235) & 2.22 & Halogen & F-NE2((HIS 201) & 3.69 & pi-pi interaction & HIS 201 & 4.81 \\
\hline & & & & & F-NE2 (HIS 299) & 3.2 & Pi-Alkyl & VAL 163 & 5.36 \\
\hline & & & & & F-OD1(ASP 197) & 3.45 & & & \\
\hline & & & & & F-OE2(GLU 233) & 3.14 & & & \\
\hline \multirow[t]{5}{*}{$4 \mathrm{e}$} & Hydrogen bon & -.--- & & Halogen & F-OE1((GLU 233) & 2.93 & Pi-Alkyl & TRY 62 & 4.48 \\
\hline & & H-0 (GLY 309) & 2.28 & Accptor-aceptor & $0-0$ (GLN 302) & 2.98 & & & \\
\hline & & H-0 (GLN 302) & 2.01 & & & & & & \\
\hline & & O-H (ARG 346) & 2.35 & & & & & & \\
\hline & & H-OD1 (ASP316) & 2.16 & & & & & & \\
\hline Co ligand & Hydrogen bon & O-H (ARG 267) & 2.33 & Donar -Donal & H-H (ARG 346) & 2.35 & ----- & & \\
\hline
\end{tabular}

Target protein has their active sites where the compound shows maximum number of interaction with protein. The complete dataset was docked and found to bind at the same active site position. Amino acids are intimately involved in the binding ligand to protein and form a complex. The residue that is significant for binding interaction and thus comprising the binding pocket of target protein are shown in Table 4. Docking studies reveled that these amino acids present in the target proteins pocket involves in the binding interaction with the selected compounds.

These complex structures reveal essential interactions between the inhibitor and the protein and these interactions are taken as the reference for the hydrazone derivative (4a-e). The co-crystallized ligand are forms hydrogen bond interaction with the residues GLY 309, GLN 302, ARG 346, ASP316, ARG 267) (Figure 5) which are present within the ATP binding pocket. The ligand is also further stabilized by a number of hydrophobic contacts with the residues. The five hydrazone derivatives (4a-e) shown in Figure 1a were taken for docking studies. These compounds are synthesized and their structures have been determined by $\mathrm{IR},{ }^{1} \mathrm{H}$ and ${ }^{13} \mathrm{CNMR}$ spectroscopy. The docking studies clearly reveal that some of these compounds bind efficiently to the enzymes of pig pancreatic alphaamylase. Binding score of autodock 4.2 varies between -7.8 to -8.9 for compounds 3a-g tested for pig pancreatic alpha-amylase (Table 5) Out of the five hydrazone derivatives analyzed, compound $4 \mathrm{~b}$ and $4 \mathrm{~d}$ forms the best interaction with pig pancreatic alphaamylase.

The compound $4 \mathrm{a}$ and $4 \mathrm{~d}$ has the highest binding score of -8.9 and 8.7. The fluorine, oxgen atom on hydrazone compound forms hydrogen bond with the hydrogen atom of ALA 198, ARG 195, and HIS 299 of pig pancreatic alpha-amylase (Figure 3 and Table 6). Compound $4 \mathrm{~d}$ having a binding score of -8.9 makes hydrogen bonds with the active site residue ASP 300, GLU 233, LYS200 and ILE 235 of enzyme (Figure 4). Re-docking of the inhibitor from the co-crystallized complex structure (Figure 5) of pig pancreatic alphaamylase resulted in a binding score of -7.8 , which is comparable to the scores found for compound $4 \mathrm{~b}$ and $4 \mathrm{~d}$ (Table 5). The re-docked conformation of co-crystallized ligand (Figure 2) resembles the conformation of the hydrazone derivative (compound $4 \mathrm{~b}$ and $4 \mathrm{~d}$ respectively).

\section{Conclusion:}

We describe the synthesis and evaluation of five hydrazone derivatives as $\alpha$-amylase inhibitors. The structures of all synthesized compounds were confirmed by elemental and spectroscopic analysis (IR, $1 \mathrm{H}$ and 13C-NMR). The biological potential of synthesized compounds was investigated through in vitro $\alpha$-amylase inhibition activity. The results showed that some of the synthesized compounds exhibited significant inhibitory activities. The compound 5-((1Z,3Z)-3-(benzo[d][1,3]dioxol-5-yl)-3((4-chloropyridin-2-yl)imino)prop-1-en-1-yl)-2-(difluoromethoxy) phenol (4b) in $100 \mu \mathrm{g} / \mathrm{mL}$ concentration showed remarkable inhibition of $81.35 \%$. Docking studies of compound 4a-e were performed against active site of pig pancreatic alpha amylase (PDB ID: 3L2M). It has been revealed from docking studies that the bonding interactions found between $4 \mathrm{~b}$ and $4 \mathrm{~d}$ with pig pancreatic $\alpha$-amylase are similar to those responsible for $\alpha$-amylase inhibition by acarbose.

\section{References:}

[1] Neustadt J \& Pieczenik SR, Molecular Nutrition and Food Research 2008 52:780 [PMID: 18626887]

[2] Mooradian AD \& Thurman JE, Drugs 1999 57:19 [PMID: 9951949]

[3] Bashary R et al. Curr Diabetes Rev. 2019 [PMID: 31237215].

[4] S LS et al. Carbohydr Polym. 2019 209:350 [PMID: 30732817].

[5] Ben Lamine J et al. Environ SciPollut Res Int. 2019 26:9739 [PMID: 30729433].

[6] Rasouli H et al. Food Funct. 2017 8:1942 [PMID: 28470323]. 


\section{BIOINFORMATION \\ Discovery at the interface of physical and biological sciences}

[7] de Sales PM et al. Food Chem Toxicol. 2017 109:962 [PMID: 28288931].

[8] Jung Met al. Current Medicinal Chemistry, 2006 13:1203 [PMID: 16719780]

[9] Kumar R et al. Asian Pacific Journal of Tropical Biomedicine 2011 1:316 [PMID: 23569783]

[10] Warjeet Singh L, Journal of Medicinal Plants Research 2011 5:677 [PMID: 31288194]

[11] Hui H et al. Chinese Medicine 2009 4:4 [PMID: 19523223]

[12] Donath MY \& Ehses JA, Proceedings of the National Academy of Sciences 2006 103:12217 [PMID: 16894143]

[13] Noor A et al. Current Science 200894 :1070 [PMID: 30471396]

[14] Wang J et al. Protien 1999 36:1 [PMID: 31014051]

[15] Yadav V et al. Int. Immunopharmacol. 2011 11:295 [PMID: 21184860]

[16] Rao et al. Med. Chem. Lett. 2010 20:6508 [PMID: 20926293]

[17] Ibrahim MA et al. Acta Pol Pharm. 2016 73:1235 [PMID: 29638064].

[18] Trinh BTD et al. J Ethnopharmacol. 2016 20:186 [PMID: 27041401].

[19] Unnikrishnan PS et al., Pharmacogn Mag. 2015 11:S511 [PMID: 27013787]
[20] Teng H et al., Crit Rev Food Sci Nutr. 2017 57:3438 [PMID: 26854322]

[21] Buchholz T et al. Phytother Res. 2016 30:260 [PMID: 26632284].

[22] Lin, A. S et al. Genes Nutr. 2011 6:125 [PMID: 30805021]

[23] Akcok, I \& Cagir, A. Bioorg. Chem. 2010 38:139 [PMID: 20457464]

[24] Liu X. F et al. J. Med. Chem. 2011 46:3469 [PMID: 21624712]

[25] Ung, S et al. Chem. Pharm. Bull. (Tokyo) 2006 54:368 [PMID: 30440682]

[26] Gondi M et al. J Food Sci Technol. 2015 52:7883 [PMID: 26604360];

[27] Striegel Let al. Front Nutr. 2015 2:3. [PMID: 30789924]

[28] Yousefi A et al. Int J Biol Macromol. 2015 78:46 [PMID: 25843662].

[29] Ibrahim MA et al. Acta Pharm. 2014 64:311 [PMID: 25296677].

[30] Li, X. H et al. Acta Pharmacol. Sin. 200728 : 2040 [PMID: 18031621]

[31] Morris GM et al. J Comput Chem. 200930 :2785 [PMID: 19399780]

[32] Trott O et al. J Comput Chem. 201031 : 455 [PMID: 19499576]

[33] Bernstein FC et al. J Mol Biol 2012 112: 535 [PMID: 875032]

[34] B. Nickavar \& Yousefian N, Iran. J. Pharm. Res. 2009 8:53 [PMID: 27054662]

Edited by P Kangueane

Citation: Balu et al. Bioinformation 15(7): 523-529 (2019)

License statement: This is an Open Access article which permits unrestricted use, distribution, and reproduction in any medium, provided the original work is properly credited. This is distributed under the terms of the Creative Commons Attribution License 


\section{BIOINFORMATION \\ Discovery at the interface of physical and biological sciences}
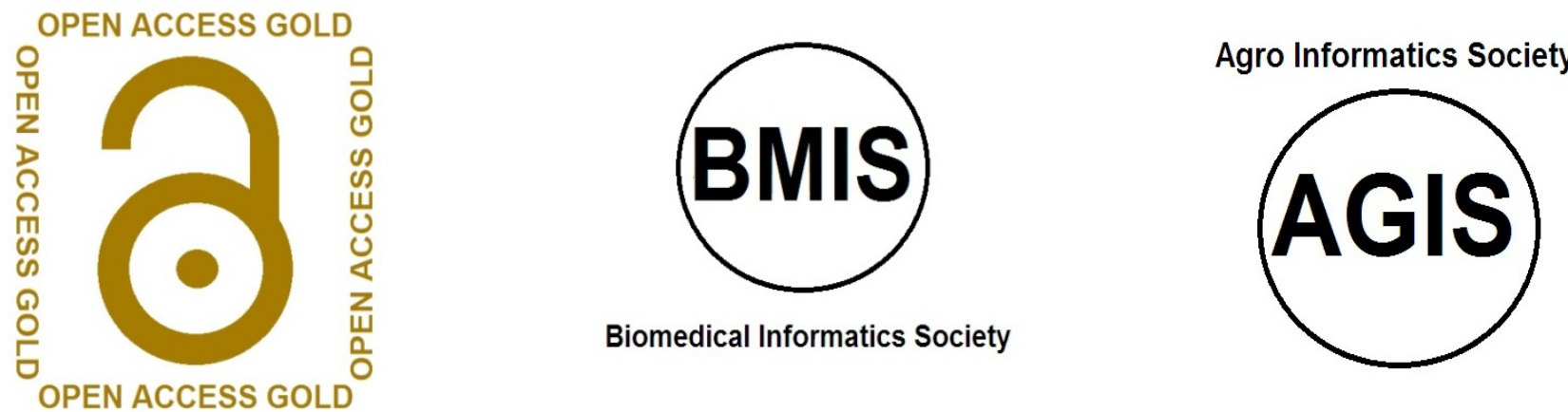

BIOMEDICAL

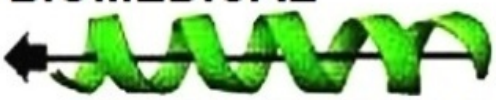

INFORMATICS, the publisher presents

BIOINFORMATION since 2005 ...

The journal is indexed in
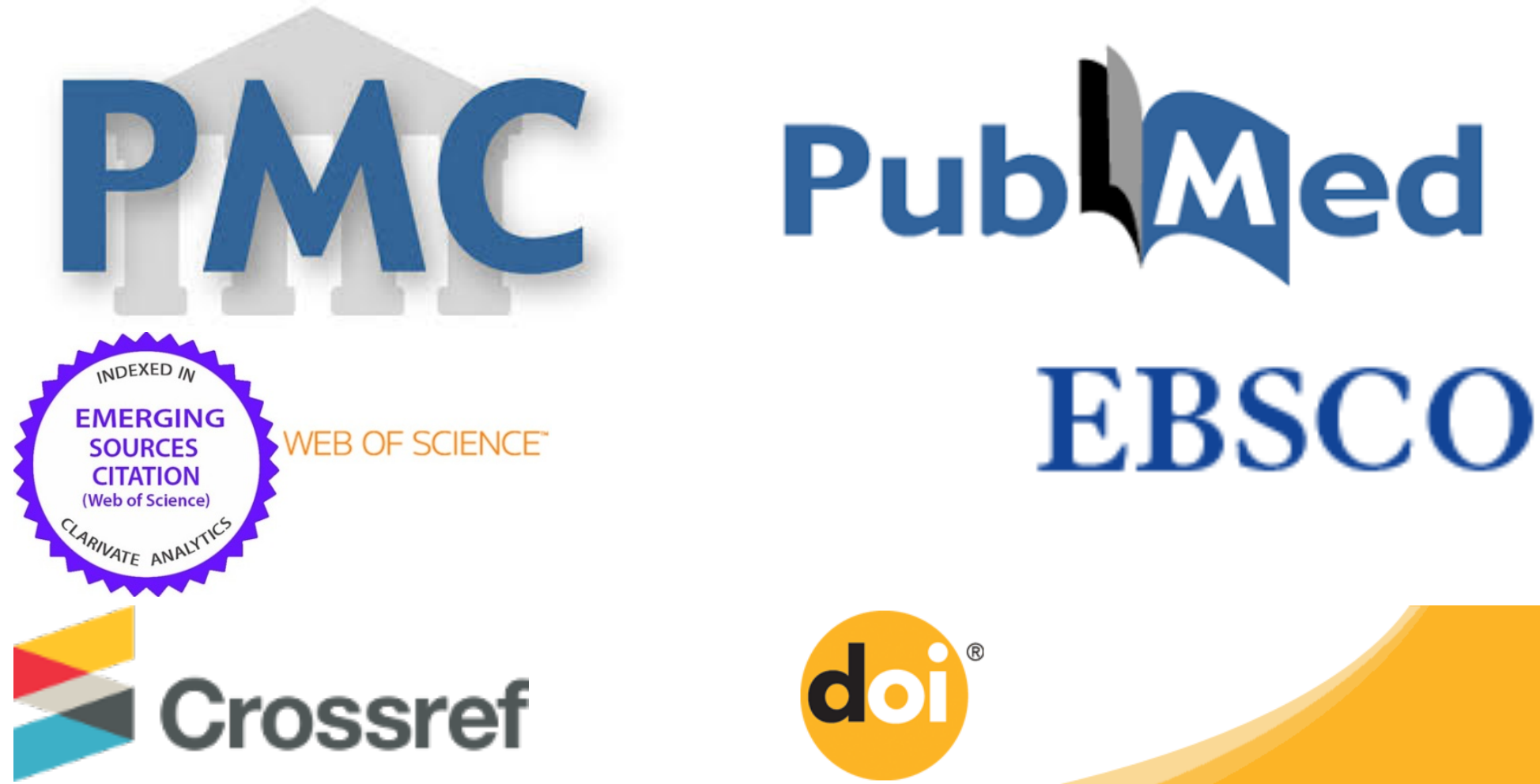